\title{
Model Digital Signature Pada Dokumen Formal Akademik
}

\author{
Henderi*1 $^{1}$, Devi Rositawati ${ }^{2}$, Pipin Romansyah ${ }^{3}$ \\ ${ }^{1}$ Program Studi Magister Teknik Informatika Fakultas Sains dan Teknologi Universitas Raharja, \\ ${ }^{2}$ Program Studi Sistem Informasi Fakultas Sains dan Teknologi Universitas Raharja, \\ ${ }^{3}$ Program Studi Sistem Komputer Fakultas Sains dan Teknologi Universitas Raharja \\ E-mail : ${ }^{* 1}$ henderi@ raharja.info, ${ }^{2}$ devi.rositawati@raharja.info, \\ ${ }^{3}$ pipinromansyah@raharja.info
}

\begin{abstract}
Abstrak
Sistem digital signature diterapkan untuk meningkatkan kualitas pelayanan penerbitan dokumen. Digital signature pada dokumen memiliki arti bahwa pihak yang menandatangani telah mengetahui dan menyetujui dokumen. Di sisi lain, penelitian terdahulu menyatakan bahwa model digital signature memiliki kelemahan dari sisi mengidentifikasi dan memverifikasi keaslian citra tanda tangan. Penelitian ini bertujuan mengembangkan model digital signature dengan validasi keaslian signature yang baik, dan mempercepat layanan penerbitan dokumen. Model digital signature dikembangkan dengan metode agile yang dimodifikasi. Pengembangan model dilakukan melalui design, construction, testing, evaluation dan delivery. Hasil pengujian menunjukan bahwa model digital signature yang dikembangkan pada penelitian ini terbukti mempercepat layanan penerbitan dokumen dengan validasi yang baik dan menyederhanakan proses bisnis penerbitan dokumen.
\end{abstract}

Kata Kunci-Signature, Dokumen, Agile

\begin{abstract}
Digital signature system is implemented to improve the quality of document border services. A digital signature on a document means that the signatory knows and approves the document. On the other hand, previous research states that the digital signature model has weaknesses in terms of identifying and verifying the authenticity of the signature image. This study aims to develop a digital signature model with validation of the authenticity of good signatures and accelerate document binder services. The digital signature model was developed using modified agile methods. Model development is done through design, construction, testing, evaluation, and delivery. The test results show that the digital signature model developed in this study is proven to accelerate document publishing services with good validation and simplify the document publishing business process.
\end{abstract}

Keywords-Signature, Document, Agile 


\section{PENDAHULUAN}

Universitas Raharja diresmikan berdasarkan Surat Keputusan Menteri Riset, Teknologi dan Pendidikan Tinggi Republik Indonesia nomor: 254/KPT/I/2019 tertanggal 12 April 2019. Surat Keputusan itu merupakan izin penggabungan Akademi Manajemen Informatika (AMIK) dan Sekolah Tinggi Manajemen Ilmu Komputer (STMIK) Raharja menjadi Universitas Raharja (UR).

Universitas Raharja berkomitmen untuk menciptakan sumber daya manusia yang tangguh, memiliki daya saing yang tinggi dalam era globalisasi. Menghasilkan tenaga intelektual dan profesional, serta mampu berkembang dalam cakrawala yang lebih luas. Manajemen Universitas Raharja diera revolusi industri 4.0 telah terjadi perubahan atau disrupsi, perubahan tersebut wajib diantisipasi untuk menyesuaikan atau merubah pola pelaksanaan dan pola perencanaan yang matang, agar semua yang direncanakan seirama dengan perkembangan global. Penerapan tanda tangan elektronik perlu diimplementasikan pada dokumen elektronik karena dapat menyediakan proses verifikasi terhadap keaslian dokumen yang diterima [2].

Universitas Raharja melaksanakan prinsip kerja bersama saling mengisi pada tugastugas yang bersifat lintas pelaksanaan tugas dan dengan motto Terencana, Terukur, Terealisasi dan Efisien, Efektif, Elegan. Karena itu, semangat perubahan perlu dilakukan oleh sivitas akademika Universitas Raharja. Semangat itu dilakukan bertujuan meningkatkan kinerja universitas, kualitas pelayanan kepada mahasiswa dan efisiensi. Salah satu proses bisnis yang perlu diperbarui untuk mencapai tujuan itu adalah penerbitan dokumen formal akademik.

Dokumen formal akademik itu diantaranya adalah dokumen validasi kuliah kerja praktek (KKP) dan tugas akhir mahasiswa. Penerbitan dokumen validasi KKP dan tugas akhir mahasiswa pada Universitas Raharja dilakukan sebagai persyaratan mahasiswa melaksanakan KKP dan tugas akhir. Kedua dokumen formal akademik ini dinyatakan sah bila semua persyaratan telah diterpenuhi. Persyaratan tersebut diantaranya ditanda tangani oleh Ketua Program Studi dan Dekan Fakultas sebagai pengesahannya. Hasil observasi dan wawancara menemukan permasalahan pada kegiatan pengesahan kedua dokumen formal akademik tersebut. Proses pengesahan dokumen validasi KKP dan tugas akhir itu memerlukan waktu yang relatif lama dan tidak efisien. Hal ini disebabkan dokumen memerlukan tanda tangan Ketua Program Studi dan Dekan Fakultas secara manual sebagai pengesahannya. Setelah disahkan, dokumen diserahkan kepada Bagian Registrasi Perkuliahan dan Ujian (RPU). RPU merubah status mata kuliah menjadi kuliah kerja praktek atau tugas akhir menjadi 'OK' pada kartu studi tetap mahasiswa setelah menerima validasi KKP dan tugas akhir yang disahkan. Penelitian ini bertujuan untuk memecahkan permasalahan tersebut dengan cara mengembangkan model signature pada dokumen formal akademik di Universitas Raharja.

\subsection{LITERATURE REVIEW}

Ada beberapa penelitian tentang digital signature. Diantaranya Rochman [1], Nugraha dkk. [2], dan Perdana dkk. [4] yang membahas penerapan digital signature pada dokumen. Penerapan digital signature memerlukan kesiapan sumber daya manusia, kesesuian proses, dan kesadaran pengguna dalam menerapkannya [1], [2], [4]. Digital signature perlu diterapkan pada dokumen elektronik karena dapat menyediakan proses verifikasi kebasahan dokumen [2].

Dokumen elektronik tersebut digunakan untuk keperluan transaski atau kesuaian proses bisnis. Tanda tangan merupakan salah satu dari sekian banyak atribut personal yang diterima secara luas untuk verifikasi indentitas seseorang, alat pembuktian kepemilikan berbagai transaksi atau dokumen di dalam masyarakat [3]. Keberadaan tanda tangan dalam sebuah dokumen menandakan bahwa pihak yang menandatangani dokumen tersebut sudah mengetahui dan menyetujui isi suatu dokumen [5].

Pengembangan dan penerapan digital signature pada dokumen dilakukan menggunakan beberapa metode. Diantaranya menggunakan metode ciri gradien dan curvature [3], metode jaringan syaraf tiruan [5], dan metode algoritma kriptografi [7]. Pada kelompok penelitian ini, 
metode yang digunakan bertujuan agar digital signature dapat digunakan untuk memvalidasi dokumen elektronik. Tujuan ini dikuatkan penelitian Nugraha [2], yang memperhatikan aspek kompleksitas implementasi, keamanan dan kesesuaian proses bisnis tata naskah pada penerapan digital signature.

\section{METODE PENELITIAN}

Penelitian dilakukan dengan pendekatan agile yang diterapkan Mahendra [8]. Pengembangan sistem dengan pendekatan agile dalam penelitian ini dinyatakan sebagai metodologi pengembangan software yang berbasis pada pengembangan iteratif, dan solusi berkembang melalui kolaborasi antar tim pengembang. Tim pengembang yang dimaksud terdiri dari sistem analis, design sistem dan programmer.

Pengembangan model digital signature di penelitian ini secara umum dilakukan secara iteratif terhadap lima kegiatan, yaitu design, construction, testing, evaluation dan delivery (Gambar 1). Kelima kegiatan tersebut dilakukan secara kolaboratif oleh Tim Pengembang. Di dalam pelakasanaannya, metode agile dimodifikasi dan disesuaikan pada beberapa tahapan sehingga dapat diilustrasi seperti Gambar 1. Kegiatan iteratif dilakukan hampir pada setiap kegiatan, di mana kegiatan design merupakan tahapan yang paling dominan diiterasi.

Pada tahap design, kegiatan design dilakukan untuk memecahkan permasalahan kurang optimalnya pelayanan fakultas dalam hal penerbitan dokumen formal akademik berupa dokumen validasi kuliah kerja praktek dan tugas akhir mahasiswa. Pada tahap contruction, kegiatan dilakukan untuk membuat aplikasi extended system dari aplikasi SIS maupun SIS+ yang ada di Universitas Raharja. Pada kegiatan contruction, pengembang sistem melakukan pekerjaannya dengan memperhatikan desain dan tabel persyaratan kuliah kerja praktek dan persyaratan tugas akhir yang ada di Tabel 1 dan Tabel 2.

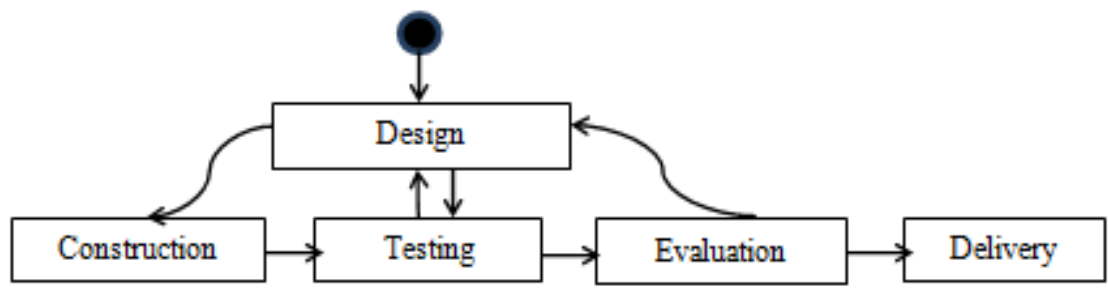

Gambar 1. Tahapan penelitian menggunakan metode agile (dimodifikasi)

Tabel 1. Persyaratan mengambil kuliah kerja praktek

\begin{tabular}{|c|l|}
\hline No. & \multicolumn{1}{|c|}{ Persyaratan } \\
\hline 1. & Indeks prestasi kumulatif minimal 2,10 \\
\hline 2. & Jumlah SKS yang telah lulus minimal 70 atau 100 \\
\hline 3. & Biaya bimbingan telah lunas \\
\hline 4. & $\begin{array}{l}\text { Mata kuliah analisa sistem informasi dan IT research sudah } \\
\text { lulus }\end{array}$ \\
\hline 5. & $\begin{array}{l}\text { Melakukan proses validasi kelayakan mengikuti kuliah } \\
\text { kerja praktek }\end{array}$ \\
\hline 6. & Seminar proposal telah dibuat \\
\hline 7. & Pembimbing 1 orang \\
\hline 8. & $\begin{array}{l}\text { Melakukan bimbingan dan membuat laporan dalam 1 } \\
\text { semester }\end{array}$ \\
\hline 9. & Kulah kerja praktek dilaksanakan secara mandiri \\
\hline
\end{tabular}


Tabel 2. Persyaratan mengambil kuliah tugas akhir

\begin{tabular}{|c|l|}
\hline No. & \multicolumn{1}{|c|}{ Persyaratan } \\
\hline 1. & Indeks prestasi kumulatif minimal 2,10 \\
\hline 2. & $\begin{array}{l}\text { Jumlah SKS yang telah ditempuh sesuai kurikulum dan tidak ada } \\
\text { nilai D dan E }\end{array}$ \\
\hline 3. & Biaya bimbingan dan ujian sidang telah lunas \\
\hline 4. & Mata kuliah kuliah kerja praktek telah lulus \\
\hline 5. & Melakukan proses validasi kelayakan mengikuti tugas akhir \\
\hline 6. & Melaksanakan seminar proposal \\
\hline 7. & Pembimbing ada 2 orang \\
\hline 8. & Melakukan bimbingan dan membuat laporan dalam 1 semester \\
\hline 9. & Tugas akhir/skripsi dilakukan mandiri \\
\hline
\end{tabular}

Di bagian lain, kegiatan testing dilakukan untuk menguji apakah model digital signature yang dikembangkan sudah valid dari sisi input, process dan output. Selanjutnya, tahapan evaluation dilakukan untuk mengetahui apakah model yang dikembangkan sudah sesuai dengan kebutuhan. Pada tahap akhir, model yang telah diuji diberikan kepada stakeholder dan siap diimplementasikan.

\section{HASIL DAN PEMBAHASAN}

Model digital signature yang dikembangkan pada penelitian ini digambarkan dalam bentuk design code. Sementara hasil implementasi model yang dikembangkan digambarkan dalam bentuk tampilan salah satu dokumen akademik yang ada di Universitas Raharja.

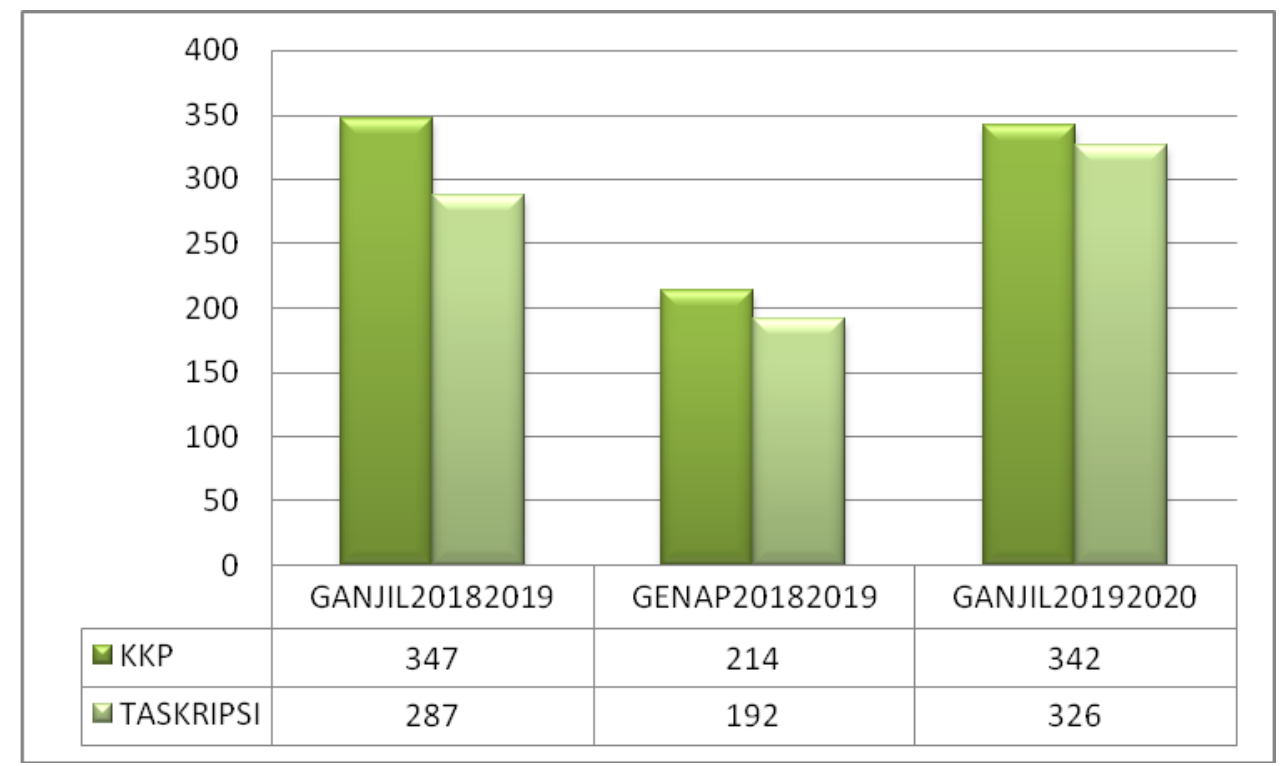

Gambar 2. Grafik Jumlah Mahasiswa yang Mengambil Mata Kuliah KKP dan Tugas Akhir

Berdasarkan grafik pada gambar 2 dinyatakan bahwa mahasiswa yang mengambil mata kuliah kkp dan tugas akhir mencapai 200 orang setiap semesternya. Dapat dilihat bahwa dekan dan kaprodi harus memberikan tanda tangan pada form akademik yang diajukan oleh mahasiswa untuk mengambil mata kuliah tersebut. 


\subsection{Design Code Model Digital Signature}

Model digital signature yang dikembangkan pada penelitian ini merupakan aplikasi Extended Students Informatioan Services (SIS) maupun SIS+ (e-SIS) di Universitas Raharja. eSIS adalah aplikasi STUDENTS iLEARNING SERVICES ${ }^{+}$(SIS+) yang dikembangkan dengan menambahkan modul yang berisi model digital signature.

Selanjutnya, modul model digital signature tersebut digunakan untuk mencetak dokumen akademik yang memerlukan tanda tangan pejabat yang berwenang sebagai bentuk pengesahan. Model digital signature yang dikembangkan ditunjukan pada design code pada Gambar 3., dan design function di Gambar 4. View code pada Gambar 3. menunjukan design dan fungsi code pada model digital signature yang dikembangkan dengan fitur adobe dreamweaver.

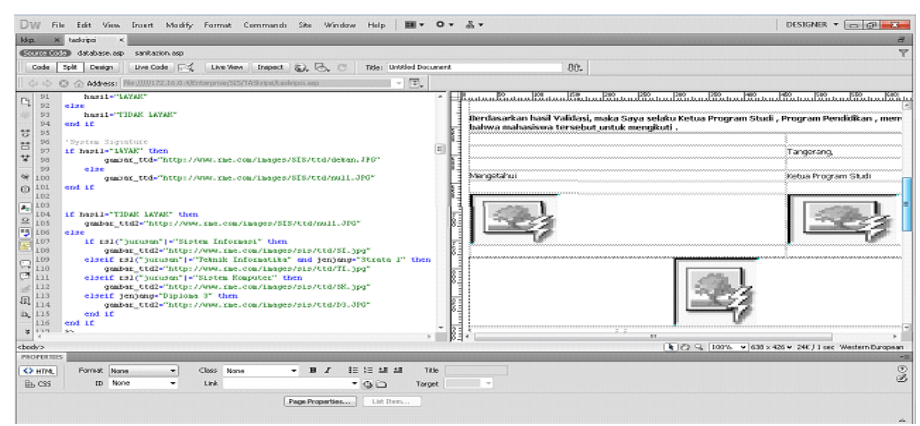

Gambar 3. Design Code Digital Signature
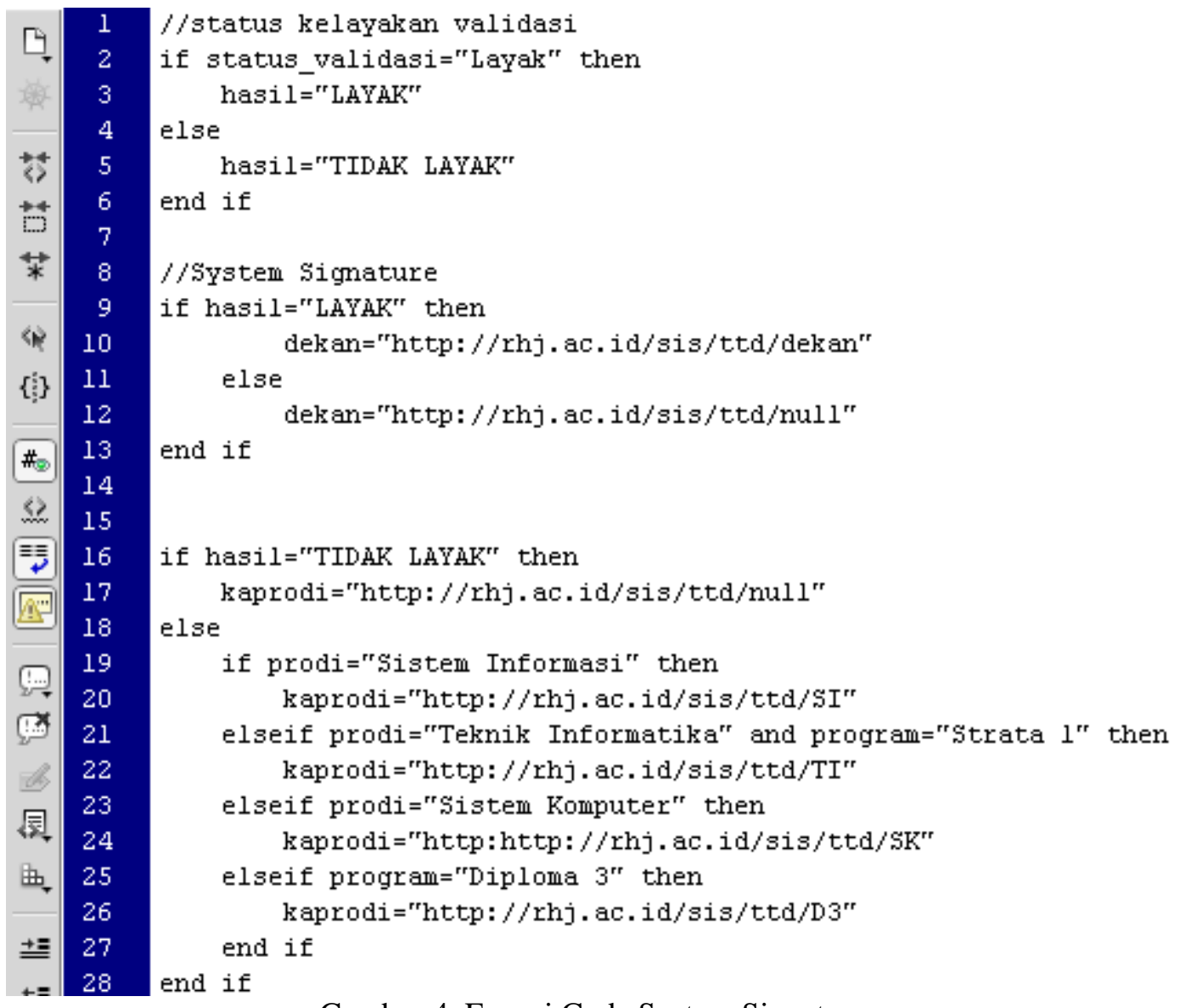

Gambar 4. Fungsi Code System Signature 
Gambar 4. menunjukan fungsi-fungsi yang digunakan pada model digital signature yang dikembangkan. Perintah pada baris 9 sampai 13 merupakan fungsi untuk menampilkan tanda tangan Dekan Fakultas, sedangkan perintah di baris 16 sampai 28 adalah fungsi untuk menampilkan tanda tangan Ketua Program Studi. Fungsi digital signature pada Gambar 4 menerapkan konsep relational algebra [9] untuk mempercepat operasional query.

\subsection{Hasil Implementasi Model Digital Signature}

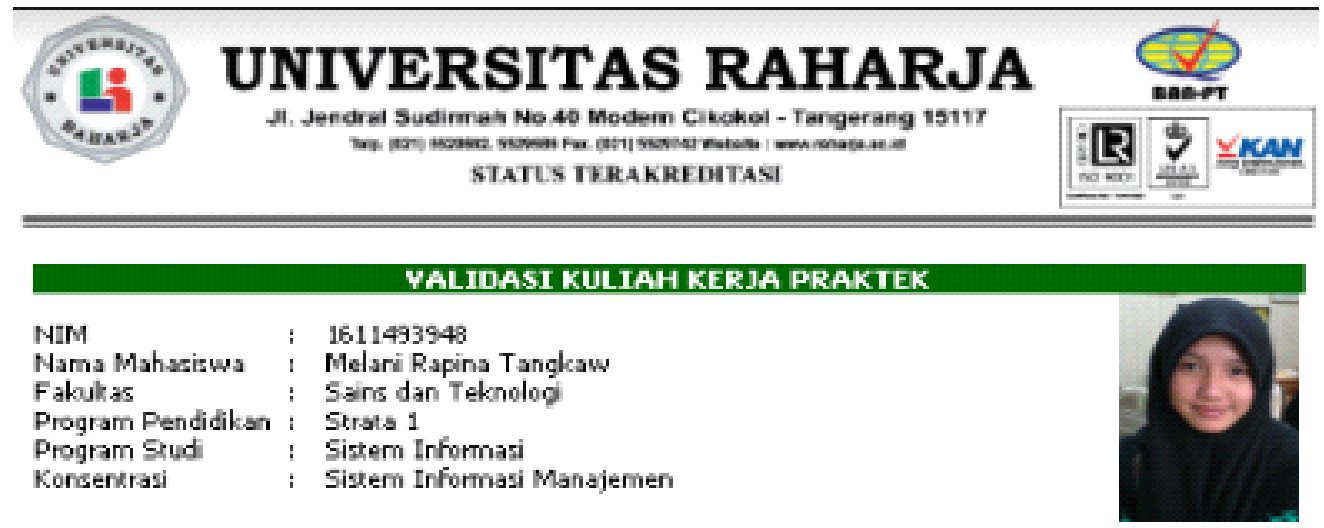

\begin{tabular}{|c|c|c|c|c|c|}
\hline $\begin{array}{l}\text { Jumlah IPK teralchir minimal } \\
\text { Jumlah SKS vang tolsh lulus minimal }\end{array}$ & t & $\begin{array}{l}2.10 \\
100\end{array}$ & & & \\
\hline Telah ambil Mota Kuliah berikut ini & $:$ & NO & Kode MK & Mata Kulah & SKS \\
\hline & & 1 & SI100 & Analisa Sistem Informasi & 3 \\
\hline & & 2 & MJ172 & IT Research & 3 \\
\hline
\end{tabular}

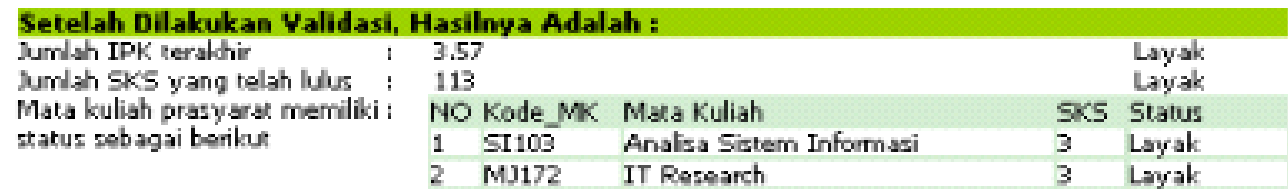

Berdasarkan hasil Yalidasi, maka Saya selake Ketua Program Studi Sistem Infermasi, Program Pendidikan Strata 1, menqatakan bahva mahasisva tersebut LAYAK untuk mengikuti KKP (Kuliah Kerja Praktek).

Saya bersedis untuk membakalkan Kuliah Kerja Praktek (KKP) saya jica suatu hari diketahui bahwa ada mata kuliah prasyarat yang sedang saya ambil di semester ini namun dinystakan tidak lulus.
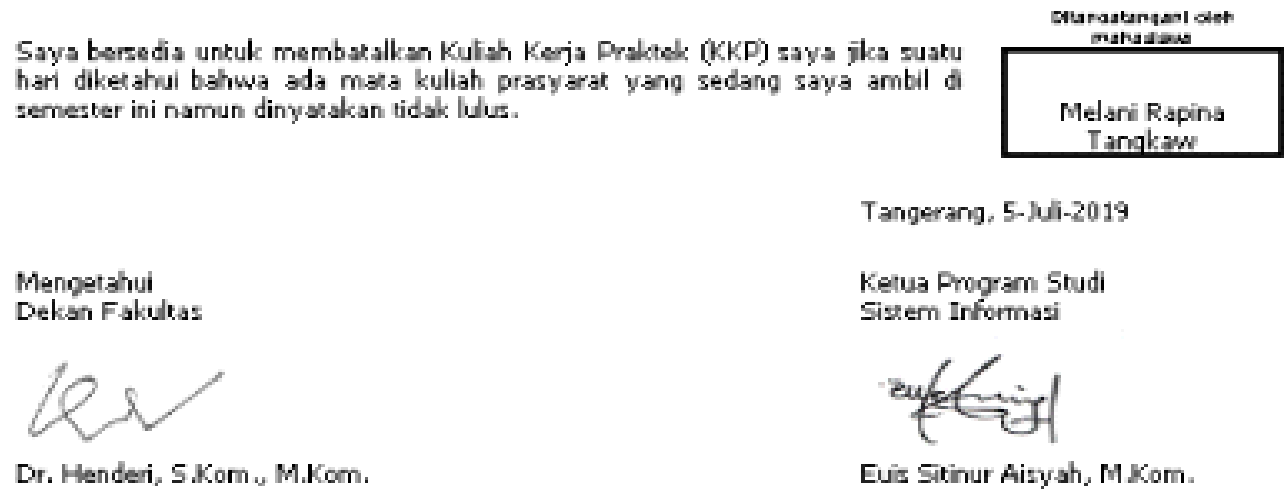

Gambar 5. Form Validasi Kuliah Kerja Praktek

Fungsi menampilkan signature yang ditunjukan pada baris 10 dan 20 di Gambar 4. fungsi ini akan dijalankan bila semua persyaratan kuliah kerja praktek telah terpenuhi atau status validasi dinyatakan layak oleh sistem. Selanjutnya sistem menampilkan formulir validasi seperti pada Gambar 5. Fungsi di baris 10 dan 20 pada model digital signatute yang dikembangkan pada penelitian ini dapat mengatasi kemampuan sistem dalam menangani verifikasi tanda tangan asli yang masih rendah. 


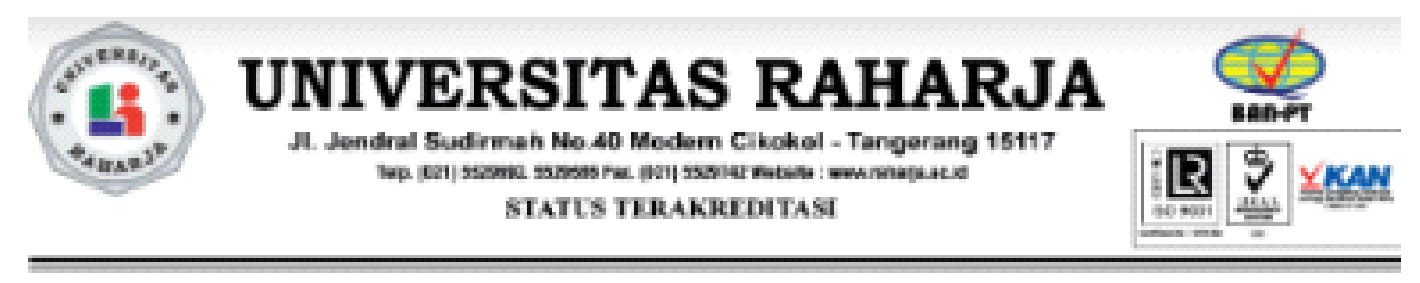

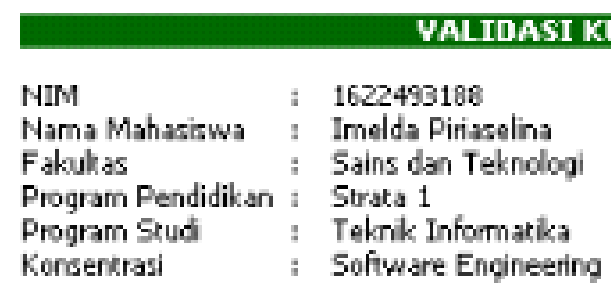

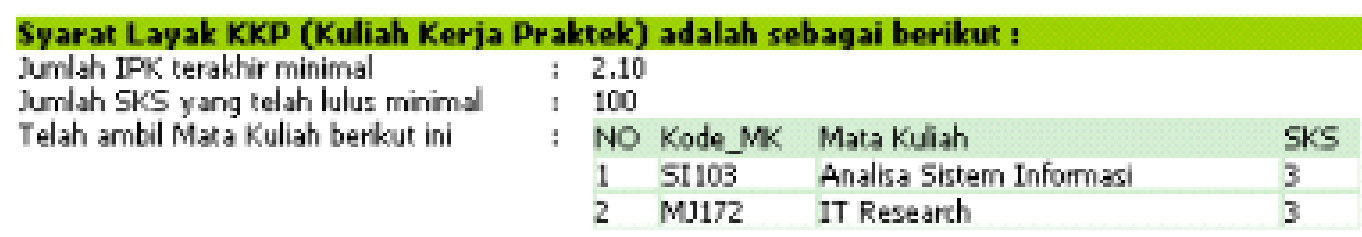

\begin{tabular}{|c|c|c|c|c|}
\hline \multicolumn{5}{|c|}{ Setelah Dilakukan Yalidasi, Hasilnya Adalah : } \\
\hline Jumlah IPK terakhir : & 3.55 & & & Layak \\
\hline Jumlah SKS yang telah lulus : & 112 & & & Layak \\
\hline Mata kuliah prasyarat memiliki 1 & NO Kode_MK & Mats Kuliah & SKS & Status \\
\hline status sebapai berikut & $1 S \operatorname{SI} 10 \overline{3}$ & Analisa Sistem Informasi & 3 & Layak \\
\hline & Mu172 & IT Research & 3 & Layak \\
\hline
\end{tabular}

Berdasarkan hasil Yalidasi, maka Saya selaku Ketua Program Studi Teknik Informatika, Program Pendidikan Strata 1, menyatakan bahwa mahasiswa tersebut LAYAK untuk mengikuti KKP (Kuliah Kerja Praktek).

Saya bersedia untuk membatakan Kuliah Kerja Praktek (KKP) says jika suatu hari dikerahui bahwa ada mata kulah prasyara yang sedang saya ambil di semester ini namun dinyatakan tidak lulus.

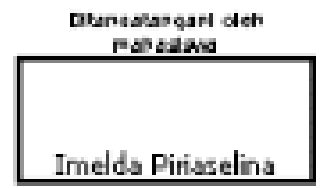

Mengetshui

Dekan Fakultas

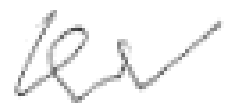

Dr, Henderi, S Kom., M.Kom.
Tangerang, 5-Juli-2019

Ketus Program Studi Teknik Informatika

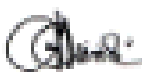

Ruli Supriøi, SKom., M.T.I.

Gambar 6. Form Validasi KKP TI S1

Code function pada baris 10 dan 20 juga berfungsi menyediakan proses verifikasi terhadap keaslian dokumen yang diterima. Code function pada model yang dikembangkan ini menguatkan model digital signatute pada penelitian Nugraha [2]. Penerapan code funtion yang dikembangkan pada model digital signature pada baris 10 dan 20 dilakukan untuk memenuhi kriteria keamanan yang dibahas dalam penelitian Iryani [6]. 
Gambar 6 merupakan fungsi menampilkan digital signature yang ditunjukan pada baris 10 dan 22 di Gambar 4 Fungsi ini akan dijalankan bila syarat KKP telah terpenuhi semua atau status validasi dinyatakan LAYAK oleh sistem dan hasilnya akan muncul seperti Gambar 6.

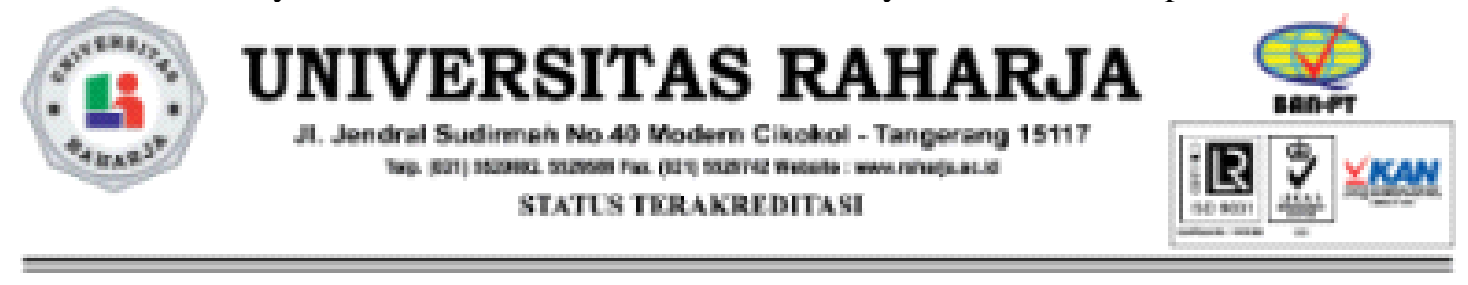

\section{VALIDASI KULIAH KERJA PRAKTEK}

$\begin{array}{lll}\text { NIM } & : 1322376041 \\ \text { Nama Mahasiswa } & \text { Ageung Ramdhani } \\ \text { Falakss } & \text { Sains dan Teknologi } \\ \text { Program Pendidikan : } & \text { Diploma } 3 \\ \text { Program Studi } & \text { : Kemputerisasi Akuntansi } \\ \text { Konaenkrasi } & \text { i } & \text { Keuangan }\end{array}$

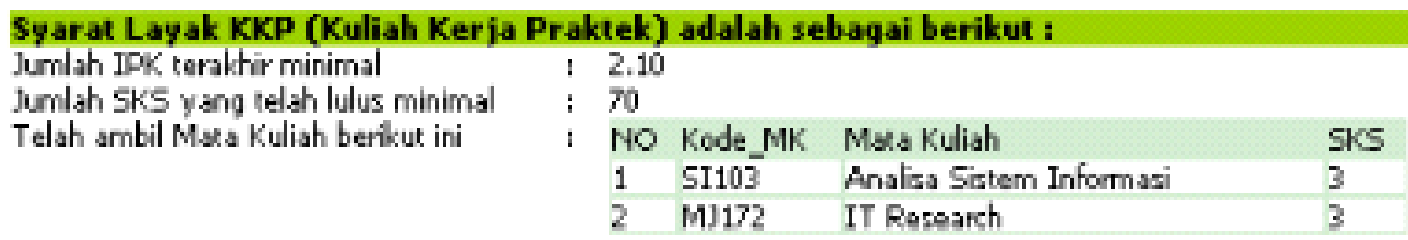

Setelah Dilakukan Yalidasi, Hasilnya Adalah:
$\begin{array}{llll}\text { Jumlah IPK teralchir } & 2.39 & \text { Layak } \\ \text { Jumlah SKS yang telah lulus : } 86 & & \text { Layak } \\ \text { Mata kuliah prasyarat memilki : } & \text { NO Kode MK Mata Kulsh } & \text { SKS Status } \\ \text { status sebagai beikut } & 1 \mathrm{SI} 03 & \text { Andisa Sistem Informasi } & 3 \text { Layak } \\ & 2 \mathrm{MJ172} & \text { IT Research } & 3 \text { Layak }\end{array}$

Berdasarkan hasil Validasi. maka Saya selaku Ketua Program Studi Komputerisasi Akuntansi, Program Pendidikan Diploma 3, menyatakan bahwa mahasisua tersebut LAYAK untuk mengikuti KKD (Kuliah Kerja Praktek).

Saya bersedia untuk membatalkan Kuliah Kerja Praktek (OKCP) saya jika suatu hari diketahui bahwa ada mata kuliah prasyarat yang sedang saya ambil di semester ini namun dinyakakan tidak lulus.

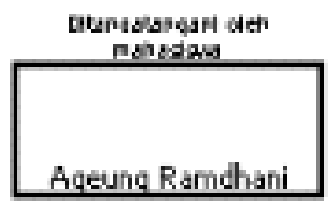

Tangerang, 5-Juli-2019

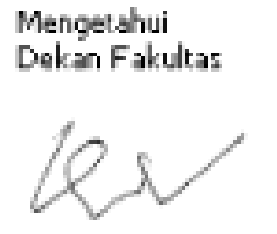

Dr. Henderi, S Kom MKom.
Ketua Program Stud Komputerisasi Akuntansi

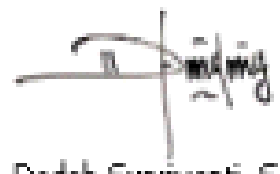

Dedeh Suprinanti, S.Kom., M.T.I.

Gambar 7. Form Validasi KKP Diploma D3

Fungsi menampilkan digital signature ditunjukan pada baris 10 dan 26 pada Gambar 4. Fungsi ini akan dijalankan bila semua persyaratan kuliah kerja praktek telah terpenuhi sehingga 
status validasi dinyatakan layak oleh sistem. Selanjutnya sistem menampilkan bentuk dokumen validasi kuliah kerja praktek seperti Gambar 7.

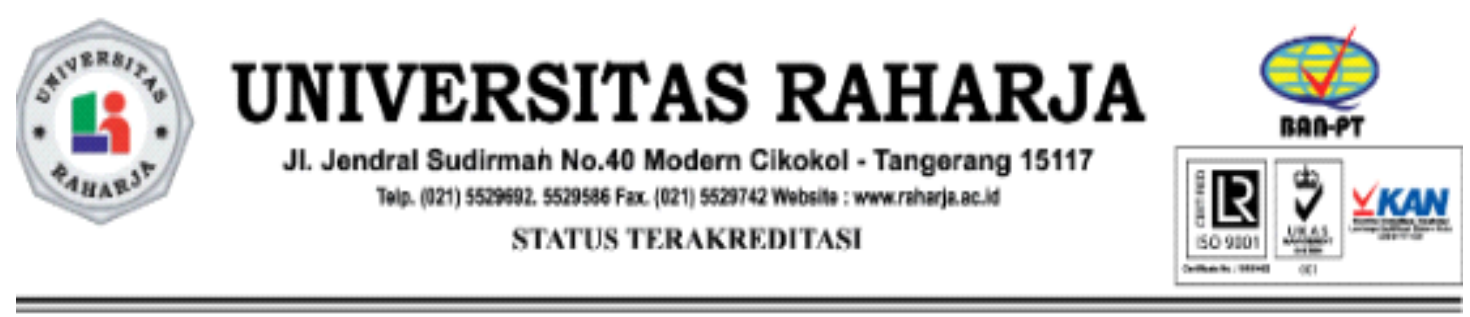

\begin{tabular}{|c|c|}
\hline & VALIDASI SKRIPSI \\
\hline NIM & 1233470568 \\
\hline Nama Mahasiswa & : Fajar Januar Eka Putra \\
\hline Fakultas & : Sains dan Teknologi \\
\hline Program Pendidkan & : Strata 1 \\
\hline Program Studi & : Sistem Komputer \\
\hline Konsentrasi & : Creative Communication and Innovative Technology \\
\hline ID Kurkulum & $: 3345$ \\
\hline
\end{tabular}

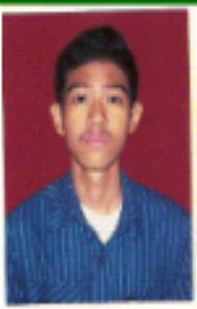

Syarat Layak Skripsi adalah sebagai berikut :
Jumlah IPK terakhir minimal
Telah lulus seluruh mata kuliah lainnya sesuai kurikulum
$\begin{array}{lll} & \\ \text { Setelah Dilakukan Validasi, Hasilnya Adalah : } & & \\ \text { Jumlah IPK terakhir } & : 3.10 \\ \text { Status mata kuliah lainnya sesuai kurikulum } & : \text { Lulus semua }\end{array}$

Berdasarkan hasil Validasi, maka Saya selaku Ketua Program Studi Sistem Komputer, Program Pendidikan Strata 1, menyatakan bahwa mahasiswa tersebut LAYAK untuk mengikuti Skripsi.

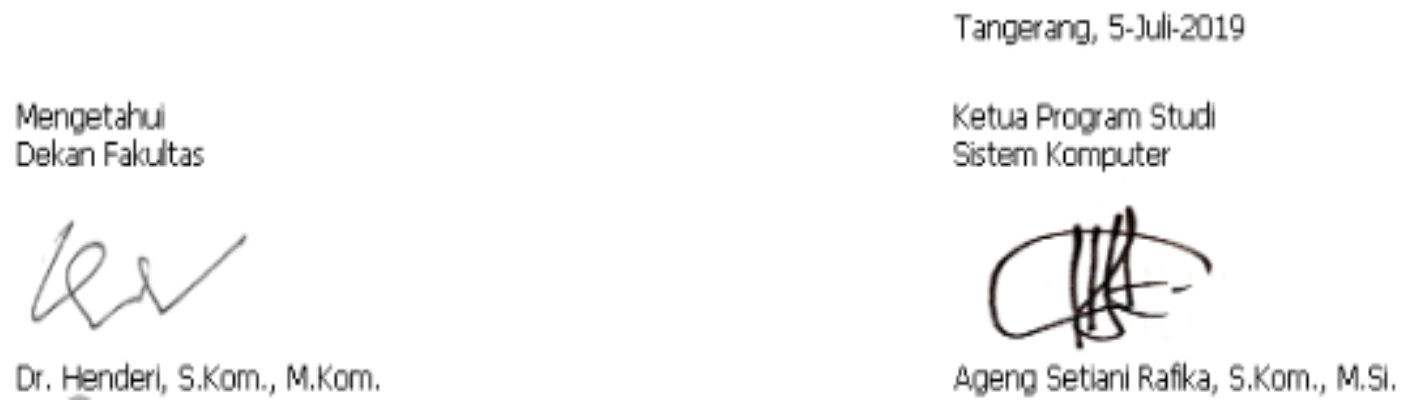

Gambar 8. Form Validasi Tugas Akhir

Fungsi menampilkan digital signature yang ditunjukan pada baris 10 dan 24 pada Gambar 4 dijalankan bila semua persyaratan tugas akhir telah terpenuhi atau status validasi dinyatakan LAYAK oleh sistem. Selanjutnya sistem menampilkan keluaran seperti pada Gambar 8 . 


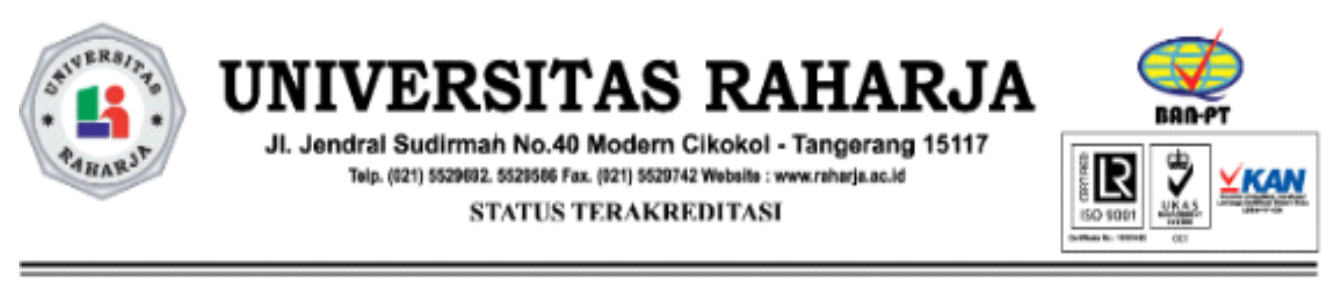

\begin{tabular}{|c|c|}
\hline & VALIDASI SKRIPSI \\
\hline NIM & : $\quad 1522489498$ \\
\hline Nama Mahasiswa & : Ardyan Aqus Prayogo Sri Handoyo Prapto \\
\hline Fakultas & : Sains dan Teknologi \\
\hline Program Pendidkan & : Strata 1 \\
\hline Program Studi & : Teknik Informatika \\
\hline Konsentrasi & : Software Engineering \\
\hline ID Kurikulum & 2246 \\
\hline
\end{tabular}

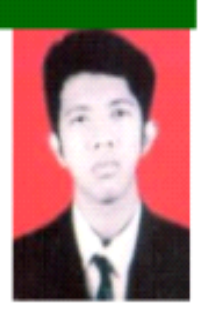

Syarat Layak Skripsi adalah sebagai berikut :
Jumlah IPK terakhir minimal
Telah lulus seluruh mata kulah lainnya sesuai kurikulum

Telah lulus seluruh mata kuliah lainnya sesuai kurikulum

\begin{tabular}{|c|c|c|}
\hline IDE tarakkir & & \\
\hline Jumlah IPK terakhir & $: 3.06$ & LAYAK \\
\hline Status mata kuliah lainnya sesuai kurikulum & : Lulus semua & LAYAK \\
\hline
\end{tabular}

Berdasarkan hasil Validasi, maka Saya selaku Ketua Program Studi Teknik Informatika, Program Pendidikan Strata 1, menyatakan bahwa mahasiswa tersebut LAYAK untuk mengikuti Skripsi.

Mengetahui

Dekan Fakultas

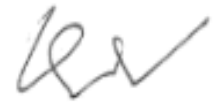

Dr. Henderi, S.Kom., M.Kom
Tangerang, 5-jul-2019

Ketua Program Studi

Teknik Informatika

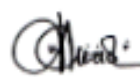

Ruli Supriati, S.Kom., M.T.I.

Gambar 9. Form Validasi TA/Skripsi TI S1

Pada bagian lain, Gambar 9 adalah fungsi menampilkan digital signature yang ditunjukan pada baris 10 dan 22 di Gambar 4 fungsi ini akan dijalankan bila semua persyaratan tugas akhir telah terpenuhi atau status validasi dinyatakan layak. Bila dinyatakan layak, maka sistem menampilkan dokumen formal akademik seperti pada Gambar 9.

Model digital signatute yang dikembangkan pada penelitian ini berbeda dengan Alfiah dkk. [5], karena pencocokan tanda tangan secara manual tidak perlu dilakukan. Hal ini dikarenakan model yang dikembangkan memiliki algoritma pemeriksaan status persyaratan mandatory pada dokumen universitas. Model digital signature akan menerbitkan dokumen universitas secara lengkap jika persyaratan mandatory telah terpenuhi. Dengan demikian, model digital signatute yang dikembangkan pada penelitian ini dapat menjaga validitas dokumen dan meningkatkan kecepatan penerbitan dokumen. Namun demikian, model yang dikembangkan memiliki keterbatasan bila pejabat yang berwenang mengesahkan dokumen. Hal ini disebabkan digital signature pada model dijadikan sebagai fungsi code signature pada saat implementasi.

\section{KESIMPULAN}

Model digital signature yang dikembangkan melalui penelitian ini terbukti mempercepat proses penerbitan dokumen format universitas, dan dapat menjaga validitas dokumen yang diterbitkan. Penerapan model yang dihasilkan menyederhanakan proses bisnis 
karena mampu melaksanakan pemeriksaan dan validasi terhadap syarat mandatory penerbitan dokumen. Di sisi lain, model yang dikembangkan memiliki keterbatasan bila pejabat yang mengesahkan dokumen berganti.

\section{SARAN}

Dengan demikian penelitian lanjutan perlu dilakukan untuk menghasilkan model sejenis yang lebih adaptif terhadap perubahan pejabat yang mengesahkan dokumen.

\section{DAFTAR PUSTAKA}

[1] Rochman, F. F., 2016, Implementasi QR Code Dan Digital Signature Untuk Menentukan Keabsahan Dokumen Krs Dan Khs (Studi Kasus Fakultas Sains Dan Teknologi Universitas Airlangga), Universitas Ailangga, Surabaya.

[2] Nugraha, A., Mahardika, A, 2016, Penerapan Tanda Tangan Elektronik Pada Sistem Elektronik Pemerintahan Guna Mendukung E-Government, Prosiding Seminar Nasional Sistem Informasi Indonesia (SESINDO), pp. 359-364.

[3] Widodo, A. W., Harjoko, A., 2015, Sistem Verifikasi Tanda Tangan Off-Line Berdasar Ciri Histogram Of Oriented Gradient (HOG) Dan Histogram Of Curvature (HoC), Jurnal Teknologi Informasi dan Ilmu Komputer (JTIIK), No. 1, Vol. 2, pp. 1-10.

[4] Perdana, R. A., Anbiya, D. R., Grahitandaru, A., 2019, Penerapan Tanda Tangan Digital pada Gambar Formulir C1.Plano-KWK di Pilkada Sulawesi Selatan, Jurnal Teknologi Informasi dan Ilmu Komputer (JTIIK), No. 5, Vol. 6, pp. 475-484.

[5] Alfiah, I. N., 2018, Penerapan Metode Backpropagation Neural Network Untuk Mengidentifikasi Tanda Tangan, Universitas Islam Negeri Sunan Kalijaga, Yogyakarta.

[6] Iryani, N., 2018, Penerapan Tanda Tangan Digital Menggunakan Analisis Swot Untuk Meningkatkan Keamanan Informasi Studi Kasus: Perum LKBN Antara, Universitas Mercubuana, Jakarta.

[7] Liyanti., Hakim, A.R., 2019, Perancangan Penerapan Tanda Tangan Digital Sebagai Pengembangan Sistem Pelayanan Pentashihan Al Quran Digital, Jurnal SISTEMASI, No 1, Vol 8, pp. 41-54.

[8] Mahendra I., Yanto Deny T.E., 2018,"Agile Development Methods Dalam Pengembangan Sistem Informasi Pengajuan Kredit Berbasis Web, Studi Kasus: Bank BRI Unit Kolonel Sugiono", Jurnal Teknologi dan Open Source, Vol.1 No. 2, pp. 13-24.

[9] Kurniasih J., dan Henderi, 2018, Kajian Optimasi Query Dengan Pendekatan Heuristik, Jurnal Dinamika Informatika, Vol.7 No. 2, pp. 18-28. 